\title{
Research on the Design of College Students Ideological and Political Network Education Platform
}

\author{
Yongkun $\mathrm{Yu}$ \\ Jilin Agricultural University, Changchun 130118, China
}

\begin{abstract}
Ideological and political education has always been an important work in Colleges and universities. In the new era of information, the network ideological and political education system comes into being, and gradually becomes an important part of the construction of information technology in Colleges and universities. This paper, from education, journalism, psychology, ethics and network technology, starts from the interdisciplinary perspective of the plight of to study ideological and political education in Colleges and universities. From the three aspects of design function, system composition and countermeasures, study platform design of College ideological and political education based on the network environment. Influence on the ideological and political education, moral norms and information organizations and so on, so they become high political and high information literacy talents needed for the social development.
\end{abstract}

Keywords: ideological and political education; network education; platform design.

\section{Introduction}

With the rapid development of information technology, the network has put forward new challenges to the traditional education model, and it also provides a new carrier, platform and great information resources for talent training. Since the eighteenth of the party, the Central Committee of the Communist Party of China attaches great importance to the construction of network position and network propaganda and ideological work. General Secretary Jinping Xi repeatedly stressed that it is necessary to take online media propaganda as the core of ideological work according to the development needs of the situation. It is required to make full use of new means of dissemination to innovate university ideological propaganda work, grasp the initiative of public opinion in the network, and clearly put forward requirements on the innovation of ideological and political education in network [1]. The Ministry of Education advocates the counselors of Colleges and universities to establish micro-blogging number, and carries on the comparison, encourage the political work cadres and students to proceed peer to peer communication through network, and make full use of various network interactive means to carry out information release, student management, psychological counseling, resources sharing work and so on, to promote the strong development of ideological and political education work [2, 3]. It has become quite essential to establish a scientific and effective mechanism of construction for a university network ideological and political education platform, put forward the ideal university network ideological and political education platform mode, introduce new methods, establish new idea, and achieve new results. It provides basis for the College students' ideological and political education in theoretical research and practical operation [4].

\section{Current Situation and Problems of Ideological and Political Education of College Students}

The rapid development of the Internet technology brings the weakening of the traditional media and the development of new media, and the network has become the latest and most convenient new media. Under such kind of network environment, the ideological and political education of College students has also ushered in new challenges, the emergence of new features and new problems.

\subsection{Current Situation of College Students Ideological and Political Network Education}

Through observation and analysis, sum up the following features of the current situation of the ideological and political education in network environment.

(1) College students are increasingly widely using in the Internet. The traditional way of obtaining information and knowledge through books, television and broadcasting and the way to achieve leisure 
and entertainment, have turned to new media - the internet. Network resources obtaining is more convenient, fast and economic. Therefore, the degree of dependence of College students on the Internet also shows an upward trend.

(2) College students' ability to adapt to the network environment is strong, but the ability to identify is weak. College students are in the age of rapidly accepting new things, and after entering the university, the parents and teachers have less supervision of the students on using the internet. As a result, College students will be able to adapt to the use of the network soon. However, the identification degree of the advantages and disadvantages of these information is not directly proportional to the degree of adaptability. A lot of College students are misled and even hurt by harmful information in the network.

(3) The use of the network of ideological educators in Colleges and universities is increasing day by day. The ideological and political educators in Colleges and universities have gradually associated their classroom teaching and homework with the use of the network. Some teachers set up their own student QQ space and WeChat group as a platform for publishing information and exchanging experience

\subsection{Problems of Ideological and Political Education of College Students}

The present situation of the ideological and political education in the network environment has brought some problems remained to be solved [5].

(1) The research content of the network ideological and political education is insufficient in the depth and breadth, lagging behind the development of the network. The research on how to utilize the network environment and resources reasonably in the ideological and political education is still not systematic, and has not formed a reasonable frame structure or the theory with guiding value.

(2) Study method and dimension of the ideological education in the network environment are single, having not formed scientific and overall perspective. In consequence, there is still great development space on interdisciplinary research, scholars in various fields has not yet been able to foster strengths and circumvent weaknesses, working together in research on network ideological and political education.

\section{Design of College Students Ideological and Political Network Education Platform}

\subsection{Design Thought of Ideological and Political Network Education Platform for College Students}

Through analysis of the present situation and existing problems of ideological and political education in Colleges and universities under the network environment, we need more research on new methods to solve the problem, making the network education keep pace with the times and better service Colleges and universities. After in-depth research, from the four aspects of the school management system, knowledge management system, academic community system and information push system, build a College student ideological and political network education platform, as shown in Figure 1. 


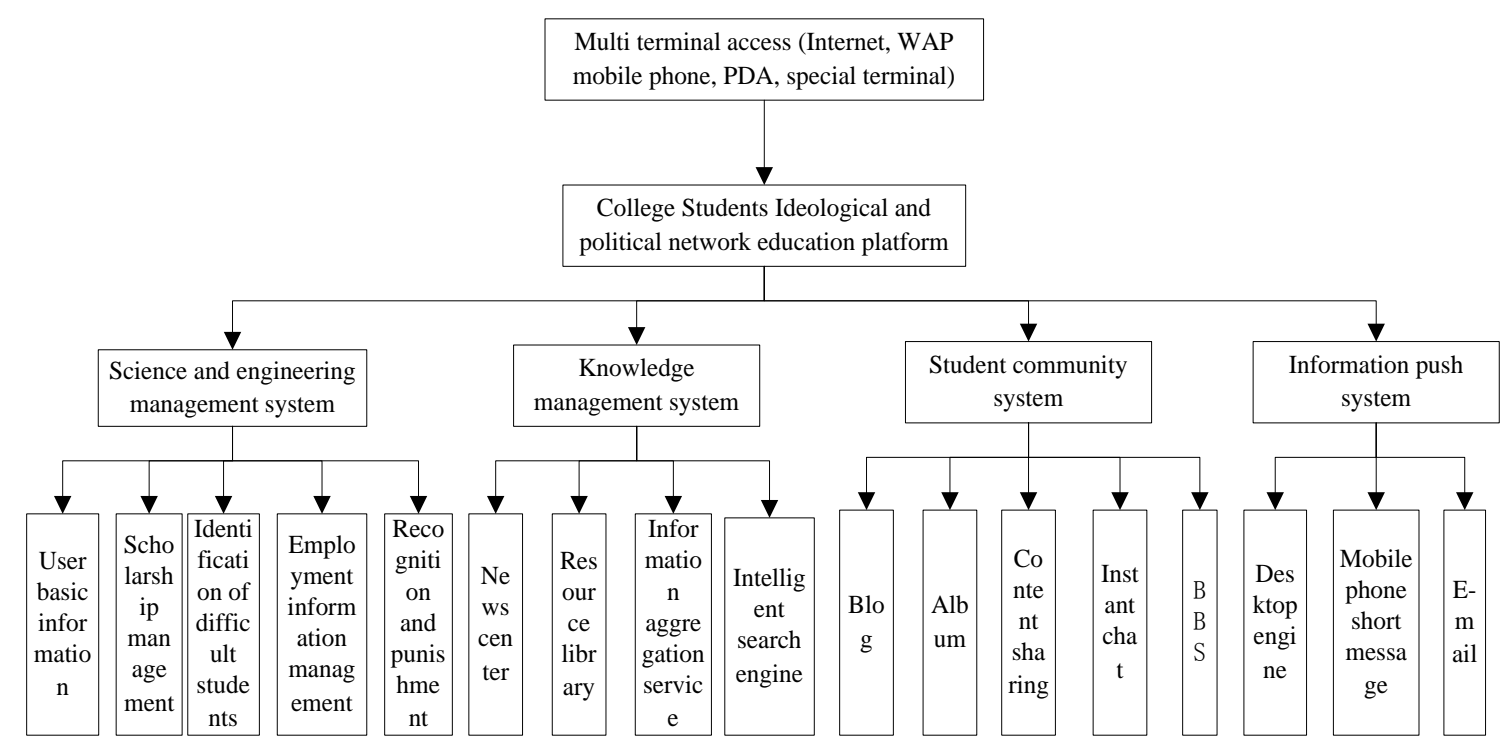

Figure 1 College students ideological and political network education platform

\subsection{Function Analysis of College Students Ideological and Political Network Education Platform}

The network platform of ideological and political education of College students supports a variety of ways of online learning, and allows the user to use a variety of terminal equipment, a variety of means and system for fast and convenient information exchange, break through the limit of time and space, and achieve the open learning that integrates mobile learning and social learning in one.

The platform is divided into four systems, the specific functions of each platform are as follows.

(1) Student Work Management System

Student management system provides the basic users information service, scholarship management, difficult students identification, employment information management, rewarding and punishment and other functions. Students can openly and transparently access to information in the system, independently complete a scholarship application etc. activities, change the students passively accepting the role under traditional teaching management mode, and mobilize the activity of students to participate in school management activities, so as to improve the daily work efficiency and quality.

(2) Knowledge Management System

Knowledge management system includes news center, resource base, information aggregation service, and intelligent search engine, which creates a high efficient network learning environment for users. News center issue the information like a notice of activity and function module updates and so on, and timely provide the latest information. Resources library is composed of self-built resources and out-purchased resources, providing high-quality and rich education resources and teaching application software tools, and achieving good resource sharing mechanism. Information aggregation service can call other site information, support the clipping of any page on the web for users. Through adding, restructuring, consolidating of multiple sites, effectively integrate various information spread on the Internet. Intelligent search engine proceeds the technologies like sorting, data mining, neural network, decision tree, association rules, case-based reasoning and so on of user habits, improve the retrieval accuracy and effect, and help users to quickly and accurately find the required information.

(3) Student Community System

Student community system has the functions of blog, photo album, BBS, content sharing, instant messaging and so on, allowing students users and teachers users to equally express their views and share information, which provides a full range of interactive platform for the users. This system will improve the trust degree through the verification and authentication of the user's real information, so as to establish effective and stable social network connection with other users. 


\section{Use of Network Education Platform of Ideological and Political Education for College Students}

\subsection{Realization of Main Function Module}

After the completion of the ideological and political network education platform construction, the key of how to have a lasting and in-depth appeal and influence on students is to build the content. Take correct orientation and content of education as a key of construction, strive to enhance the connotation of network interactive community. Not only meet the demand of ideological and political education, but also conform to the interest of students, and improve the service bonding degree and influence of education of network ideological and political education.

On the one hand, the construction of ideological and political education network platform needs to achieve the purpose of education. For this, actively carry out the construction of the party building, employment guidance, psychological counseling, award diligence helps loans, daily affairs management and other work, and timely release of relevant information to encourage students to participate in. In the existing social network platform, the using rate topic, voting, photo album, and Sky-Drive is higher in College students. Therefore, we should make full use of these functions to carry out rich online activities and achieve more effective publicity and education results [6].

The following table summarizes the reference model for using main functions of the network platform to carry out the ideological and political education.

Table 1 The ideological and political education activities of College students

\begin{tabular}{|c|c|c|c|c|c|c|}
\hline & Topics & $\begin{array}{l}\text { Photo } \\
\text { album }\end{array}$ & Voting & Sky-Drive & $\begin{array}{l}\text { Micro-blog/ } \\
\text { blog }\end{array}$ & $\begin{array}{c}\text { Instant } \\
\text { messaging }\end{array}$ \\
\hline $\begin{array}{l}\text { Party building } \\
\text { work }\end{array}$ & $\begin{array}{l}\text { Notification, } \\
\text { publicity and } \\
\text { event news }\end{array}$ & $\begin{array}{l}\text { Activity } \\
\text { photos of } \\
\text { Party } \\
\text { members } \\
\text { style show }\end{array}$ & $\begin{array}{l}\text { Recommending } \\
\text { excellent member } \\
\text { selection and } \\
\text { positive vote }\end{array}$ & $\begin{array}{l}\text { Party school } \\
\text { information and } \\
\text { Party building } \\
\text { documents }\end{array}$ & $\begin{array}{l}\text { Thought } \\
\text { report }\end{array}$ & $\begin{array}{c}\text { Party } \\
\text { members } \\
\text { exchange }\end{array}$ \\
\hline Mission work & $\begin{array}{c}\text { Notification, } \\
\text { publicity, event } \\
\text { news }\end{array}$ & $\begin{array}{l}\text { Activity } \\
\text { photos }\end{array}$ & $\begin{array}{l}\text { Investigation and } \\
\text { research and } \\
\text { re-election }\end{array}$ & $\begin{array}{c}\text { Activity } \\
\text { planning and } \\
\text { activity } \\
\text { summary } \\
\end{array}$ & Experience & $\begin{array}{c}\text { Interviews } \\
\text { exchange }\end{array}$ \\
\hline $\begin{array}{l}\text { Employment } \\
\text { guidance }\end{array}$ & $\begin{array}{c}\text { Lecture notice, } \\
\text { recruitment } \\
\text { information, } \\
\text { Employment } \\
\text { Development } \\
\text { Report }\end{array}$ & $\begin{array}{l}\text { Activity } \\
\text { photos }\end{array}$ & $\begin{array}{l}\text { Investigation and } \\
\text { research }\end{array}$ & $\begin{array}{l}\text { Resume } \\
\text { template and job } \\
\text { reference book }\end{array}$ & $\begin{array}{c}\text { Career } \\
\text { planning }\end{array}$ & $\begin{array}{c}\text { Information } \\
\text { push and } \\
\text { interview } \\
\text { notice }\end{array}$ \\
\hline $\begin{array}{l}\text { Psychological } \\
\text { counseling }\end{array}$ & $\begin{array}{l}\text { Lecture notice } \\
\text { and event notice }\end{array}$ & $\begin{array}{l}\text { Activity } \\
\text { photos }\end{array}$ & $\begin{array}{l}\text { Investigation and } \\
\text { research }\end{array}$ & $\begin{array}{l}\text { Activity photos, } \\
\text { recommended } \\
\text { books, and } \\
\text { lecture videos }\end{array}$ & $\begin{array}{c}\text { Observation } \\
\text { of students' } \\
\text { dynamic }\end{array}$ & $\begin{array}{c}\text { Interviews } \\
\text { exchange and } \\
\text { online } \\
\text { consultation }\end{array}$ \\
\hline $\begin{array}{c}\text { Award } \\
\text { diligence help }\end{array}$ & $\begin{array}{l}\text { Notice and } \\
\text { publicity }\end{array}$ & $\begin{array}{l}\text { Award } \\
\text { photos }\end{array}$ & $\begin{array}{l}\text { Candidate } \\
\text { selection }\end{array}$ & $\begin{array}{c}\text { Scholarship } \\
\text { application form }\end{array}$ & $\begin{array}{c}\text { Observation } \\
\text { of students' } \\
\text { dynamic } \\
\end{array}$ & $\begin{array}{c}\text { Interviews } \\
\text { exchange }\end{array}$ \\
\hline $\begin{array}{l}\text { Volunteer } \\
\text { service }\end{array}$ & $\begin{array}{l}\text { Notification, } \\
\text { publicity and } \\
\text { event news }\end{array}$ & $\begin{array}{l}\text { Activity } \\
\text { photos }\end{array}$ & $\begin{array}{l}\text { Excellent } \\
\text { volunteer } \\
\text { selection }\end{array}$ & $\begin{array}{l}\text { Event planning } \\
\text { book and } \\
\text { volunteer } \\
\text { application form }\end{array}$ & Experience & $\begin{array}{l}\text { Interview } \\
\text { notice }\end{array}$ \\
\hline Other things & $\begin{array}{l}\text { Notification, } \\
\text { publicity, } \\
\text { subject } \\
\text { education, and } \\
\text { opinion } \\
\text { collection } \\
\end{array}$ & $\begin{array}{l}\text { Activity } \\
\text { photos and } \\
\text { photos of } \\
\text { excellent } \\
\text { students }\end{array}$ & $\begin{array}{l}\text { Class leadership } \\
\text { election }\end{array}$ & $\begin{array}{l}\text { Course-ware } \\
\text { analysis and } \\
\text { commonly used } \\
\text { download } \\
\text { information }\end{array}$ & $\begin{array}{c}\text { Observation } \\
\text { of students' } \\
\text { dynamic }\end{array}$ & $\begin{array}{c}\text { Interviews } \\
\text { exchange }\end{array}$ \\
\hline
\end{tabular}

\subsection{Teacher Information Module}

On the other hand, the ideological and political education network platform building must pay attention to the combining with the reality of the students, carry more close to the students' learning 
and living needs to shorten the emotional distance with the College students, stimulate the emotional resonance between the College students, and improve user viscosity. As shown in Figure 2, it is the summary of the situation for students to use ideological and political network education [7].

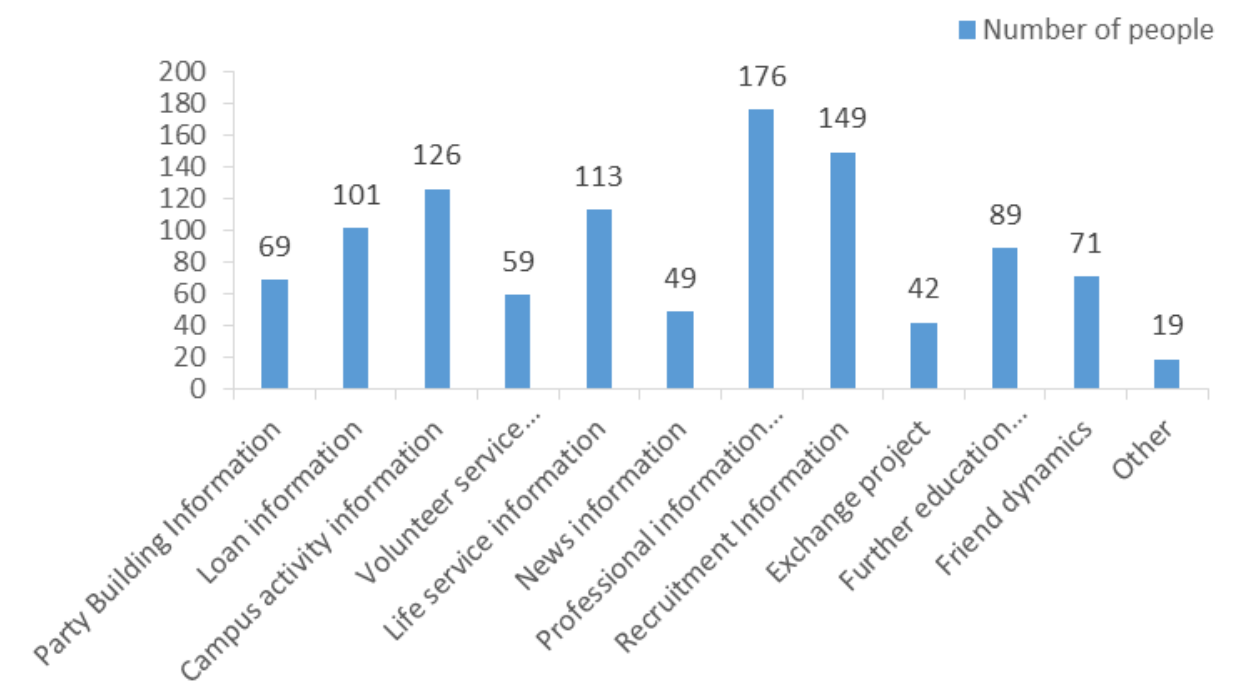

Figure 2 Categories of College students concerned about the ideological and political network education platform

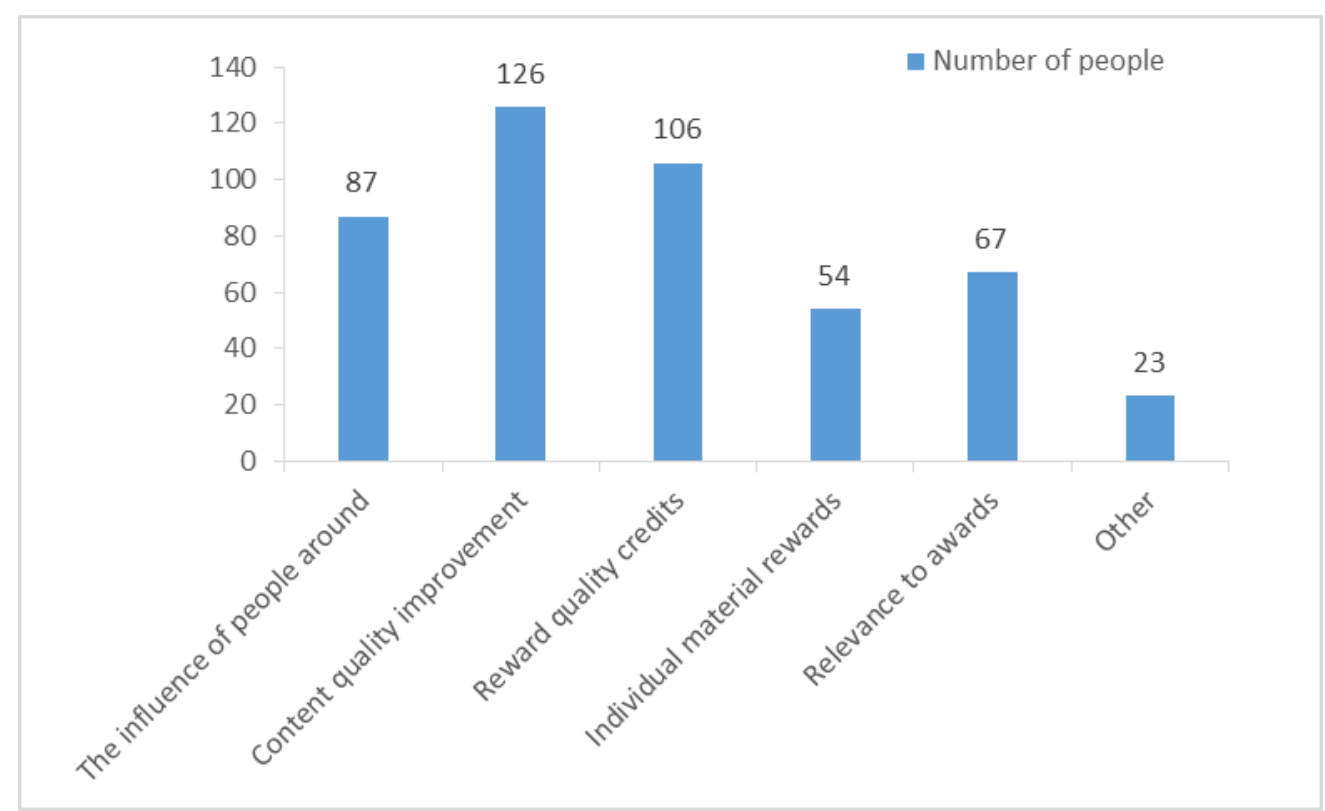

Figure 3 Factors for College students' use of ideological and political network education

According to Figure 3, it is known that the content quality is the key factor that influences the students' ideological and political education platform. In consequence, expecting to improve the using rate, in essence, it is necessary to pay attention to the construction and improvement of the content. At the same time, it can be seen that reward quality credit, influence around, and appraised awards linked has a certain promoting role in motivating students to use it.

\section{Conclusion}

Ideological and political education is a process of constant development and innovation, and the design of the network education platform of ideological and political education is an important aspect of the process. As ideological and political education workers, we must examine the basis of the construction of ideological and political education social network in theory, and gradually form in practice on the basis of theoretical discussion. In the face of the ideological and political education 
process, we are supposed to actively respond to it. Design the platform of the ideological and political education of College students based on the realistic situation. To strengthen the construction of ideological and political education of College students from the aspects of teacher training, student education and the construction of campus network environment and so on. We firmly believe that the network construction of the ideological and political education is bound to have a lot of positive and effective impact on College students so that the development of ideological and political education in Colleges and universities are full of new vitality.

\section{References}

[1] Zheng Z. The Inspiration of College Ideological and Political Education in the Age of Big Data [J]. Teaching of Forestry Region, 2015, 6: 031.

[2] Heng C A O. Use of Psychological Knowledge to Advance Ideological and Political Work of Enterprises [J]. Journal of Anhui Vocational College of Metallurgy and Technology, 2013, 1: 030 .

[3] Zhou Y. Analysis of the structure of university ideological and political online education platform [J]. 2015.

[4] Wei D. A Probe into Curriculum Reform of the Ideological and Political Education-the Education of College Applicants for Party Membership from the Perspective of Network [J]. Journal of Hebei Normal University for Nationalities, 2014, 3: 042.

[5] Xiaoju L I. Integration of Ecological Civilization Education into Ideological \& Political Theory Course in College-Seen from the Course of an Introduction to the Basic Tenets of Marxism [J]. 2014.

[6] He H. College Students' Ideological and Political Education Mode Characteristics Based on Network Perspective [J]. The Guide of Science \& Education, 2014, 6: 057.

[7] Xian L I, Rang-xin W. Behavioral Logic's Analysis on Promoting Network Ideological and Political Education [J]. Journal of University of Electronic Science and Technology of China (Social Sciences Edition), 2015, 4: 019. 